\title{
How does Information and Communications Technology Influence Turkish Students' Science Achievement?
}

\author{
Volkan Hasan KAYA ${ }^{1}$ (D) Sibel İNĊं $2, *$ (D) \\ ${ }^{1}$ The Ministry of National Education, Ankara, Turkey, volk.has.an@gmail.com \\ ${ }^{2}$ Kocaeli University, Kocaeli, Turkey, sibel.inci@kocaeli.edu.tr \\ * Corresponding Author: sibel.inci@kocaeli.edu.tr
}

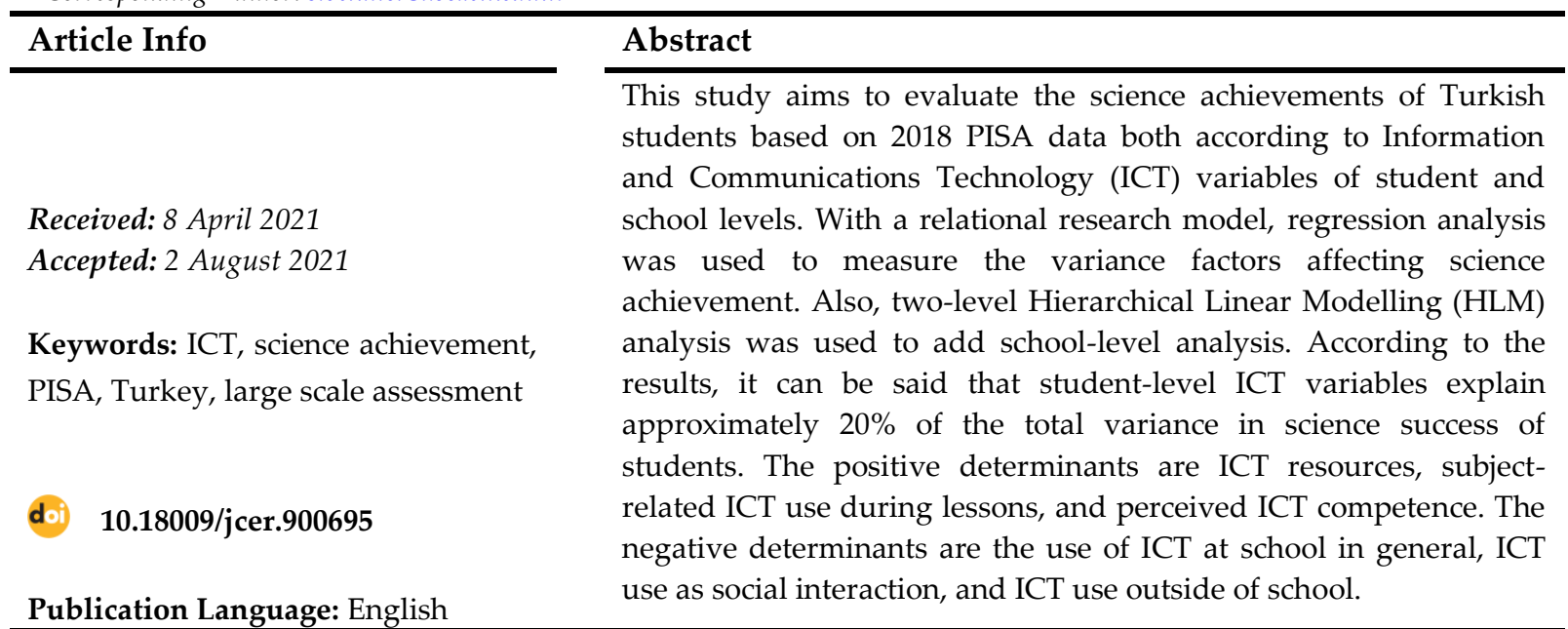

open access (

To cite this article: Kaya, V. H. \& İnci, S. (2021). How does information and communications technology influence Turkish students' science achievement? Journal of Computer and Education Research, 9 (18), 754-770. DOI: 10.18009/jcer.900695

\section{Introduction}

Due to the emergence of the sudden pandemic, Information and Communications Technology (ICT) availability and skills have become a vital issue for the world, especially in education. This new era is called a renaissance of the world, which means the world is going through a digital transformation more than ever, making people hyper-connected in new digital media and technologies (Elçiçek \& Erdemci, 2021; Park, 2017). Therefore, almost all countries share the idea that using technology in education has benefits for learners. This idea has been already in the agendas of the countries because of the developing technology and some worldwide educational policies such as skills of the 21st century and Sustainable Development Goals of UNESCO. Moreover, in accordance with the "Digital Education Action Plan of the Commission" which has 11 actions to enhance the use of technology and to improve digital competences in education, many countries try to improve their infrastructures and availability of digitalization for everybody. The Action Plan has three priorities, "making better use of digital technology for teaching and learning; developing 
digital competences and skills; improving education through better data analysis and foresight" (EU, 2018, p. 4). Also, digital competence is described in five areas by "The European Digital Competence Framework for Citizens": "information and data literacy; communication and collaboration; digital content and creation; safety and well-being; and problem-solving" (EU, 2018, p.7). All these improvements in technology and policies lead to dramatic changes in education. Using ICT in education is now unpreventable in this century.

ICT is believed to provide students with several opportunities to understand the world and construct knowledge by themselves in the frame of constructivism (Zhang \& Liu, 2016). Also, using ICT gives students lots of opportunities to individualize their learnings. In order to have the digital skills, engage and use ICT effectively, the new generation who will generate knowledge on science should have access to the Internet at home and school and have teachers with necessary digital skills. However, there is still a lot to do in the digital area to reach the educational objectives (EU, 2018).

Immediate school closures because of social distancing from the 8th of April 2020 in 191 countries affected at least 1.5 billion learners (91.3\% of total enrolled students in schools) and 63 million teachers due to Covid-19 (UN News, 2020). Countries took immediate actions in response, and most of them switched to remote learning, which led us to think about the potentials and limitations of remote learning (Hughes, 2020). According to the European Union (EU, 2020), digital technologies give learners a great opportunity for individual learning and motivation to empower their education through online collaboration. However, the integration of technology in education is still limited. Besides, during the pandemic, it became clear that there are disparities in distance education. Institute for Statistics and the International Telecommunication Union (ITU) highlighted that half of all the students globally lack a computer and no access to the Internet at home (UN News, 2020). Furthermore, 1 out of 5 learners do not have basic digital skills, and 1 out of 5 schools do not have secure broadband connections. Also, schools have just one connection or subscription for use by all students and teachers (EU, 2020). Home and school ICT availability, ICT infrastructure for Internet connectivity, network durability, and affordability of digital services have become the main issues for the countries during COVID-19. It seems that technology in learning will become more central after COVID-19. Therefore, the education systems should consider whether they are ready for shifting to remote learning by providing students with enough equipment and skills (Hughes, 2020). 
Technology usage in education can be beneficial when the teachers are well trained (EU, 2018). However, there are not enough educators with digital skills, and most of the schools still do not have broadband connections. Most teachers have problems with the quick shift to online platforms, even though countries have well-founded internet infrastructure and learners have an Internet connection at home (UN News, 2020). While most of the private schools were capable of using technologies such as video conferencing with synchronous or blended, synchronous/asynchronous timetables, the state schools could not handle the situation easily, and they found different solutions like sending posts once a week, increasing the holiday time or connections on smartphones (Hughes, 2020). It is important to understand how we can benefit from ICT in education and how it affects our learning behaviors. Also, bringing innovation and technology to education is still expected to decrease the disparities which is a case particularly in low-income countries (UN news, 2020). Therefore, we need to assess the availability of ICT and ICT engagement and get more evidence in order to assess the impact of ICT on education.

\section{ICT and Science Achievement}

Although using technology for education and empowering technological infrastructures of schools and households were on the countries' agendas for a very long time, sudden change with COVID-19 has made ICT use and availability an emergent topic in education. The Information century reveals the necessity of research on ICT and science relation. Thus, the importance of these researches and their results is increasing. One of the main sources for collecting data on ICT and assessing its impact on education is the "Programme for International Student Assessment (PISA)" of The Organization for Economic Co-operation and Development (OECD). PISA conducted the first ICT questionnaire in 2000. Since then, this questionnaire has been revised according to technological developments. In 2018, there were 50 countries performing the ICT questionnaire. As there are growing importance and swift digitalization in education and also to make the ICT questionnaire more relevant to the countries' context, it will be revised for PISA 2021 (Lorenceau, Marec \& Mostafa, 2019). The aim of ICT studies is to understand the relationship between success and ICT availability at home and school, ICT use, and ICT engagement (interest in ICT, perceived ICT competence, perceived autonomy in using ICT, and social relatedness in using ICT) (OECD, 2019). Researchers have found inconsistent results since the inclusion of ICT items in PISA 2000 (Anıl \& Özer, 2012; Cheema \& Zhang, 
2013; Delen \& Bulut, 2011; Hu, Gong, Lai, \& Leung, 2018; Luu, 2009; Kubiatko \& Vlckova, 2010; Meng, Qiu \& Boyd-Wilson, 2019; Odell, Galovan \& Cutumisu, 2020; Papanastasiou, Zembylas \& Vrasidas, 2003; Spiezia, 2010; Zhang \& Liu, 2016).

Initially, related studies started to discuss whether the quantity or quality of ICT mattered. It was first started to be discussed whether the quantity or quality of ICT mattered. One of the first studies on ICT skills in PISA was conducted by Papanastasiou et al. (2003) with USA data for ICT in PISA 2000. This study showed that frequent computer usage at home to write papers affected the science achievement of students positively. Also, Cheema and Zhang (2013) analyzed PISA 2003 with USA data and stated that how and how much they used a computer were important factors affecting achievement significantly. For PISA 2006 ICT data, Spiezia (2010) stated that in all 33 participating countries, computer use frequency correlated positively with science success although a larger effect was found with home-usage. Anıl and Özer (2012) stated that 17\% of the science achievement could be explained with ICT skills of students. They also stated that there was a high negative effect of using the Internet for entertainment on science achievement. Students using computers frequently have lower success than the students using computers less frequently. The same results with a slight difference were found by Kubiatko and Vlckova (2010) for the same year with Czech students for science achievements. According to this study, students having access to ICT had better scores in science. Moreover, students with ICT activity for the school were more successful than the ones who were not. Also, in the study of Luu (2009) for PISA 2006 ICT skills of the students in Canada and Australia about science achievement showed that students had higher science achievements if they had prior experience with ICT, used the Internet more frequently, and had confidence in basic ICT tasks. For 2009 PISA, Delen and Bulut (2011) stated that science and math achievement gaps between individuals and schools could be explained by the familiarity with ICT and the students' exposure to ICT. Review studies may also help us to understand the long-term effects of ICT skills. According to the review between the years, 2000-2012 conducted by Zhang and Liu (2016) for the relationship between ICT skills and math and science achievement in PISA with all participated countries, ICT variables at the school-level were positively related to performance but in the long term, it had negative impact depending on socio-economic status (SES). 
In the 2015 PISA, the concept of ICT engagement was proposed (Kunina- Habenicht \& Goldhammer, 2016). Results of the new questionnaire were evaluated with several studies. One of the studies including all 44 participating countries in PISA 2015 carried out by Hu et al. (2018) found that ICT availability at school and ICT entertainment had a positive effect while ICT availability at home and ICT academic use had a negative effect on students' academic success in science, math, and reading. On the other hand, attitudes toward ICT showed mixed effects; for instance, positively correlated ones are interest, competence, and autonomy in using ICT while a negative correlation was ICT enjoyment for social interaction. Also, Odell et al. (2020) found the same results for Bulgaria and Finland PISA 2015 for science achievement and ICT relationship. ICT use and availability were related to lower science achievements but science achievements of the students who were more comfortable with ICT were better. On the other hand, for the same year, Meng et al. (2019) conducted a study to compare China and Germany for all domains. The study found that interest in ICT and student achievement was related positively in China, while it was negatively related in Germany in math and science. The achievements in all domains were negatively related to ICT competence in China, but in Germany, only reading was negatively related. The autonomy of students in using ICT was positively correlated with science, reading, and mathematics achievement while social relatedness was found negatively related in both countries.

These studies show that the impact of ICT variables on achievements in different domains, between countries and between years has a complex nature, and every year its impact has been changing. Throughout these years, it is normal not to have fixed results as the technology, engagement styles, and educational policies of the countries related to ICT are still changing. Although governments try to integrate digital technologies in schools, there are not enough studies showing how to integrate ICT effectively. Therefore, there are not certain ways to provide infrastructure or devices as the impact on learning outcomes is not clear (EU, 2020). Moreover, understanding the situation about ICT in different dimensions as access, literacy, engagement of ICT will give us a chance to make comparisons before and after the Pandemic. In particular, the digital divide will be an issue to tackle for future generations. Therefore, this study will contribute to the literature by explaining the complex nature of ICT's impact on science success, particularly in Turkey. This study aims to evaluate the science achievements of Turkish students based on 2018 PISA data both 
according to student and school levels ICT variables. In the light of PISA 2018 data, "ICT accessibility and use" and "school's capacity to enhance learning and teaching using digital devices" were evaluated to see how they affect Turkish students' science success. The questions below were answered based on PISA 2018 data:

1. What is the relationship between the ICT availability at home and school, ICT use, and ICT engagement and science achievement of Turkish students?

2. What is the rate of variation in Turkish students' science achievement by differences between schools and students?

3. What is the rate at which the science achievement of Turkish students is explained by school variables considered at the second level?

\section{Method}

\section{Research Design}

This study is a descriptive quantitative study to define the relationship between student level and school level ICT variables and science achievement. The ICT familiarity questionnaire of PISA 2018 included ICT availability at home and school, ICT use, and ICT engagement (students' interest in ICT, use of ICT, perceived competence and autonomy in using ICT, and the use of social media) (OECD, 2019). In this study, a relational research model was used. Regression analysis was performed to measure the student-level ICT variables on variance factors affecting science achievement. Besides, two-level Hierarchical Linear Modelling (HLM) was used to add the school-level variables.

Sample

The data was taken from the official website of OECD, PISA available for researchers to do secondary analyses (https://www.oecd.org/pisa/data/2018database/). In this study, student-level and school-level datasets were used. Jerrim, Lopez-Agudob, MarcenaroGutierrezb and Shure (2017) stated that sample design used in PISA is probabilistic, stratified, and clustered. The sample of this research consists of 15-year-old Turkish students participating in PISA 2018. In the sample, there were 6890 students.

\section{Data Analysis}

Depending on the purpose of the study, the dependent variable is PISA 2018 science achievement. While calculating the science achievement score, because of the complexity of the data, 10 plausible values related to science were used. Students are nested within schools 
so standard errors are clustered at the school level (Jerrim et al., 2017, Rodrigues \& Biagi, 2017). Independent variables of this study are shown in Table 1.

Table 1. Student level properties and variables

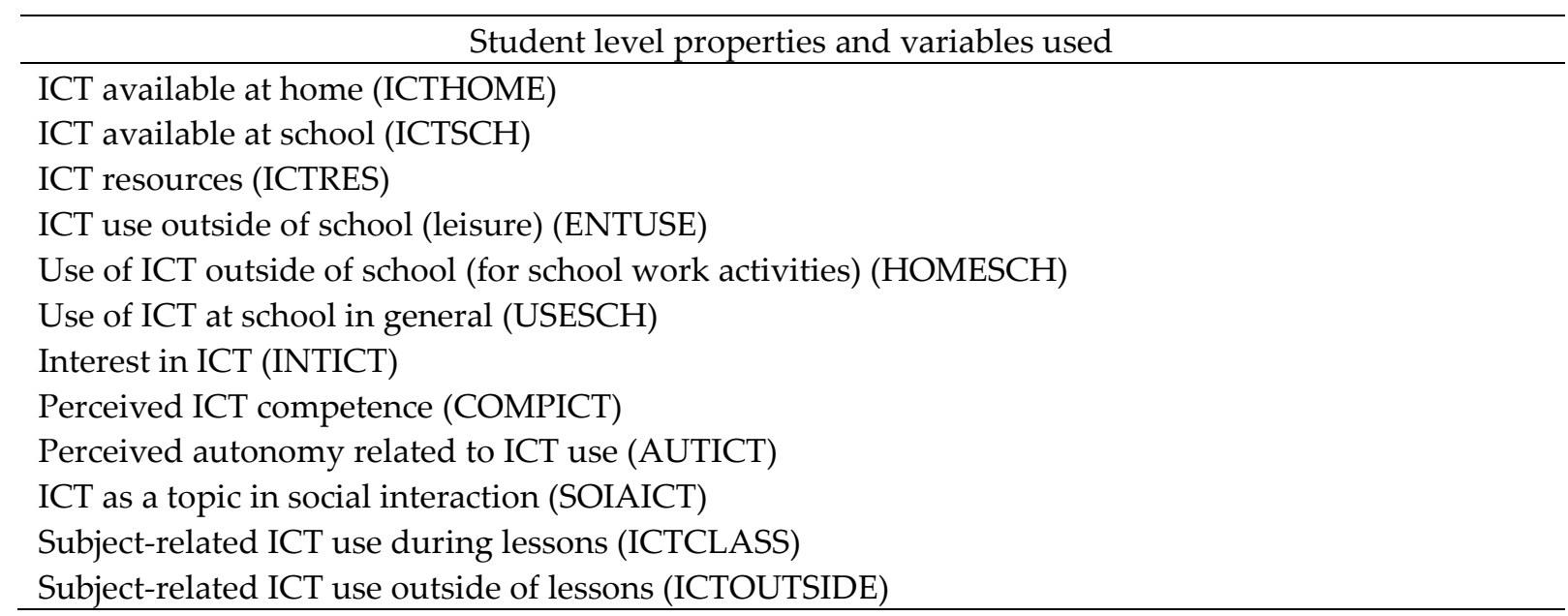

The regression analysis performed at the student level was carried out with the SPSS program. Regression analysis was conducted to measure the variance factors affecting science achievement. The linear trend at point method was used in missing data before conducting regression analysis. Independent variables and dependent variable correlations were found below 0.80. Variance Inflation Factor (VIF) was between 1.03 and 1.68 in the model. Durbin-Watson coefficients in the model were between 1.5 and 2.0. For regression analysis, the P-P Plot image in the Appendix shows that residuals are normally distributed. The school variables used in this study are shown in Table 2.

Table 2. School level properties and variables used

School level properties and variables used

The number of digital devices for instruction is sufficient (SC155Q03HA)

Teachers have the necessary technical and pedagogical skills to integrate digital devices in instruction (SC155Q06HA)

An effective online learning support platform is available (SC155Q09HA)

Number of available computers per student at modal grade (RATCMP1)

Two-level Hierarchical Linear Modelling (HLM) analysis was used for the school level (Raudenbush \& Bryk, 2002). The HLM 7.0 program was used in Hierarchical Linear Modelling analysis. Before starting the HLM analysis, bilateral correlations between the independent variables at each level were examined to determine whether there are multiple connectivity problems and the correlation coefficient values between the independent variables were found below 0.58. In the HLM program, a lost data method was performed. While SPSS data is converted into Multivariate Data Matrix Files (MDM), the missing data 
(list-wise deletion) method is used to analyze by ignoring the missing data. Also, when the kurtosis values of the independent variables are examined, it is seen that the whole independent variable is in the range of -1 to +1 . In the HLM program, for the centralization (standardization) of the variables of the levels, the first level variables were centralized around the group mean, and the second level were centralized around the general mean.

\section{Findings}

Findings Related to the First Sub-Problem

Table 3. Findings related to ICT availability and use

\begin{tabular}{llllllll}
\hline Determinant & $\mathrm{B}$ & Std. Er. & Beta & $\mathrm{t}$ & $\mathrm{p}$ & Zero-Order & Partial \\
\hline (Constant) & 508.55 & 3.91 & & 130.15 & .000 & 500.89 & 516.21 \\
(ICTHOME) & -2.48 & .45 & -.08 & -5.55 & .000 & -3.36 & -1.61 \\
(ICTSCH) & .250 & .34 & .01 & .75 & .456 & -.41 & .91 \\
(ICTRES) & 25.02 & 1.18 & .31 & 21.14 & .000 & 22.70 & 27.34 \\
(ENTUSE) & 3.07 & .80 & .05 & 3.81 & .000 & 1.49 & 4.64 \\
(HOMESCH) & -7.36 & 1.10 & -.09 & -6.72 & .000 & -9.51 & -5.21 \\
(USESCH) & -13.68 & .93 & -.18 & -14.71 & .000 & -15.50 & -11.86 \\
(INTICT) & 5.53 & .96 & .08 & 5.76 & .000 & 3.65 & 7.42 \\
(COMPICT) & 10.28 & 1.18 & .13 & 8.71 & .000 & 7.97 & 12.60 \\
(AUTICT) & 2.40 & 1.14 & .03 & 2.11 & .035 & .17 & 4.64 \\
(SOIAICT) & -8.43 & 1.16 & -.11 & -7.28 & .000 & -10.69 & -6.16 \\
(ICTCLASS) & 15.49 & .94 & .20 & 16.54 & .000 & 13.66 & 17.33 \\
(ICTOUTSIDE) & -4.23 & .99 & -.05 & -4.29 & .000 & -6.16 & -2.30 \\
\hline
\end{tabular}

$\mathrm{R}=0.44, \mathrm{R}^{2}=0.20, \mathrm{~F}(12-6877)=139.04, \mathrm{p}<.01$

Table 3 indicates that the relationship between the total variance of 10 predictive variables and the success of the students is meaningful $(\mathrm{F}(12-6877)=139.04, \mathrm{p}<.01)$. These variables explain approximately $20 \%$ of the total variance in students' success. The main determinants influencing students' science achievement positively are 'ICTRES', 'ICTCLASS', and 'COMPICT', the main negative determinants are 'USESCH', SOIAICT, and 'HOMESCH'.

Findings Related to the Second Sub-Problem

Based on the PISA 2018 data, the reliability coefficient for the achievement of science was calculated and an empty (one-way analysis of variance) model was established to determine the rate of explanation of variability in Turkish students' success in science by the differences between schools and students. 
Reliability Coefficient Regarding Science Success

To reveal the sample mean of the school universe, the reliability coefficient for science achievement is needed.

Table 4. Reliability coefficient regarding science success

\begin{tabular}{lcc}
\hline & Reliability coefficient & Number of schools \\
\hline Turkey & & \\
Breakpoint $1, \beta_{0}$ & 0.98 & 178 \\
\hline
\end{tabular}

As it is seen in Table 4 reliability coefficient of the PISA 2018 school average for Turkey $(\beta 0)$ was obtained as 0.98 . This result shows that the sample mean represents the school universe well.

\section{Empty Model (Null Model)}

While the empty (one-way variance analysis random effects) model was established, none of the variables belonging to the first and the second level were added. The equation for this model is as follows:

$$
\begin{array}{ll}
\text { Level-1 Model } & \text { Yij (Science2018) }=\beta 0 \mathrm{j}+\mathrm{rij} \\
\text { Level-2 Model } & \beta 0 \mathrm{j}=\gamma 00+\mathrm{u} 0 \mathrm{j} \\
\text { Mixed Model } & \text { Yij (Science2018) }=\gamma 00+\mathrm{u} 0 \mathrm{j}+\mathrm{rij}
\end{array}
$$

The results obtained from the empty model established for PISA 2018 science success are given in Table 5 .

Table 5. Fixed effects of empty model

\begin{tabular}{llllll}
\hline Random Effect & Coefficient & Standard error & t & s. d. & p value \\
\hline $\begin{array}{l}\text { Science Success Average, } \\
\boldsymbol{\gamma 0 0}\end{array}$ & 476.17 & 4.76 & 99.96 & 178 & $<0.001$ \\
\hline
\end{tabular}

According to Table 5, the weighted least squares estimation for PISA 2018 science achievement average is 476.17 , and there is a significant difference $(p<0.05)$.

Table 6. Estimation of variance components obtained by empty model

\begin{tabular}{llllll}
\hline Fixed effect & Standard deviation & Variance component & s. d. & $\chi 2$ & p value \\
\hline Breakpoint 1, $u 0 j$ & 62.11 & 3857.37 & 178 & 8769.56 & $<0.001$ \\
Level-1, $r j$ & 54.58 & 2979.24 & & & \\
\hline
\end{tabular}

It can be seen in Table 6 that the variance of the differences between the school averages (in-school variability) of the PISA 2018 science achievements of the students is 2979.24, and the variance of the mean differences (inter-school variability) is 3857.37. In 
addition, students' achievement scores differ significantly between schools ( $\chi 2=8769.56$, s. $\mathrm{d}$ $=178, \mathrm{p}<.001)$.

To determine how much of the variance in students' PISA 2018 science achievement originates from the student level and how much from the school level, the coefficients of inter-class and in-class correlation (@) were calculated as follows:

$$
\begin{gathered}
\varrho(\text { inter-class })=\tau 00 /(\tau 00+\sigma 2) \\
\varrho(\text { inter-class })=3857.37 /(3857.37+2979.24)=0.56 \\
\text { and } \\
\varrho(\text { in-class })=\sigma 2 /(\tau 00+\sigma 2) \\
\varrho(\text { in-class })=2979.24 /(2979.24+3857.37)=0.44
\end{gathered}
$$

When the calculations are analyzed, it can be deduced that $44 \%$ of the total variance related to students' science achievement is due to differences between students, and $56 \%$ is due to differences between schools.

\section{Findings Related to the Third Sub-Problem}

Based on the PISA 2018 data, the random coefficient regression model of the students was used to calculate the rate of explanation of the science achievement of Turkish students by the school variables considered at the second level. This model includes 4 variables: "The number of digital devices for instruction is sufficient (NofDIDEforINS)", "Teachers have the necessary technical and pedagogical skills to integrate digital devices in instruction (TECHandPEDAGSKILL)", "An effective online learning support platform is available (ONLEARNSUPPLATFORM)”, "Number of available computers per student at modal grade (NofCOMPerSTU)".

Table 7. Effects of school variables on student science achievement

\begin{tabular}{llcccc}
\hline Constant impact & Coefficient & Standard error & $\mathrm{t}$ & $\mathrm{s}$. d. & $\mathrm{p}$-value \\
\hline Corrected overall science achievement average, & $475.38^{* * *}$ & 4.54 & 104.75 & 174 & 0.000 \\
$\gamma_{00}$ & & & & & \\
Avg. NofDIDEforINS impact, $\gamma_{10}$ & $21.08^{* *}$ & 6.41 & 3.29 & 174 & 0.001 \\
Avg. TECHandPEDAGSKILL impact, $\gamma_{20}$ & -4.47 & 7.18 & -0.62 & 174 & 0.534 \\
Avg.ONLEARNSUPPLATFORM impact, $\gamma_{30}$ & 0.30 & 7.18 & 0.04 & 174 & 0.967 \\
Avg. NofCOMPerSTU impact, $\gamma_{40}$ & $-44.12^{*}$ & -17.58 & -2.51 & 174 & 0.013 \\
${ }^{*} \mathrm{p}<0.05 ;{ }^{* *} \mathrm{p}<0.01 ;{ }^{* * *} \mathrm{p}<0.001$ & & & & &
\end{tabular}

It is seen in Table 7 that when the number of digital devices for instruction in school is sufficient, there is an increase in science success and this relationship is meaningful (NofDİDEforINS $\gamma 10=21.08, \mathrm{SH}=6.41, \mathrm{p}<.001$ ). It can be seen that as computer availability per student at school increases, science success decreases and this relationship is meaningful 
(NofCOMPerSTU $\gamma 40=-44.12, \mathrm{SH}=-17.58, \mathrm{p}<.013$ ). "Teachers have the necessary technical and pedagogical skills to integrate digital devices in instruction" decreases science achievement but this relationship is not significant (TECHandPEDAGSKILL $\gamma 20=-4.47, \mathrm{SH}=$ $7.18, \mathrm{p}<.534)$. Online learning support platforms seem to increase science success, but this relationship is not significant (NLEARNSUPPLATFORM $\gamma 30=0,30, \mathrm{SH}=7,18, \mathrm{p}<.967$ ).

Table 8. Estimation of variance components obtained by empty model

\begin{tabular}{llllcl}
\hline Fixed effect & Standard deviation & Variance component & s. d. & $\chi^{2}$ & p value \\
\hline Level-2 error term, u0 & 58.95 & 3475.46 & 174 & 7872.83 & 0.000 \\
Level-1 error term, rij & 54.58 & 2979.36 & & & \\
\hline
\end{tabular}

Using the data in Table 8, the following process was performed for PISA 2018 science achievement in order to demonstrate how much the school variables reduce the random error variance at the second level:

$$
\begin{gathered}
\mathrm{Q}=(\sigma 2 \text { (unconditional) }-\sigma 2 \text { (conditional) }) / \sigma 2 \text { (unconditional }) * 100 \\
Q=((3857.37-3475.46) / 3857.37) * 100=9.9
\end{gathered}
$$

It is seen that approximately $10 \%$ of the error variance at this level decreased after the school characteristics variables were added to the model. This data means that school variables explain approximately $10 \%$ of the school level variance. According to the results obtained in the unconditional model analysis, $56 \%$ of the total variance related to students' science achievement was found to result from the difference between schools. It was found that only $6 \%(10 \% * 56 \%)$ of the Turkish students' science achievement variables could be explained by the school variables included in the model.

\section{Discussion}

The ICT use seems to be inevitable in this century that is witnessing technological developments and also crises occurring and affecting the whole world at the same time. Therefore, we aimed to analyze the students' access and engagement of ICT to get more evidence on the impact of ICT on science education. According to the findings related to the first sub-problem of the study, i.e., the relationship between the ICT availability and engagement and the science achievement of Turkish students based on PISA 2018, it can be concluded that the ICT engagement variables of students explain approximately $20 \%$ of the total variance in students' science success. 
According to the findings related to the second sub-problem of the study, 'ICTRES', 'ICTCLASS', and 'COMPICT' are the main determinants influencing students' science achievements positively. Also, 'ENTUSE', 'INTICT' have a low positive significant impact on science achievements. There are inconsistent results obtained from other studies on the positive effects of different variables. In contrast with this study, Erdoğdu and Erdoğdu (2015) stated that the reason 'ICTCLASS' was negatively related to achievements in Turkey might be because browsing the Internet at school distracted student's attention from schoolwork. Different from our study, 'COMPICT' in Germany was found not to be related to math and science achievement but 'COMPICT' had a negative effect on achievement in China in the study of Meng et al. (2019). Whereas, in our study as well as in the studies of $\mathrm{Hu}$ et al. (2018) and Odell et al. (2020), it was found that there was a positive effect on students' achievements. As in this study, in the study of Odell et al. (2020), Bulgarian and Finnish students who are more comfortable with ICT are more successful in science. Similarly, confidence in computers was found as an important predictor of math and science performances in Turkey in the studies of Delen and Bulut (2011). Also, 'ENTUSE' was found to have a small positive impact on achievements in this study as in the study of $\mathrm{Hu}$ et al. (2018). On the other hand, 'USESCH', 'SOIAICT' and 'HOMESCH' were found to be the determinants influencing science achievement negatively. In $\mathrm{Hu}$ et al. (2018), 'SOIAICT' was found negatively related to achievement, too. Similarly, in the study of Meng et al. (2019), social relatedness in using ICT was negatively related to students' achievement in China and Germany. In contrast with our study, in PISA 2015, only HOMESCH and ENTUSE were found positively associated with achievement (Rodrigues \& Biagi, 2017). In addition, 'ICTHOME' and 'ICTOUTSIDE' had a small negative impact on science achievement in this study.

In addition, in this study, 'ICTSCH' and 'AUTICT' were found not to be related to science academic achievements of students in Turkey. In contrast, Erdoğdu and Erdoğdu (2015) stated that access to the Internet at school increased students' achievement in science in Turkey. Also, in the study of Meng et al. (2019) in China and Germany autonomy in using ICT was positively related to students' achievement. In addition, Hu et al. (2018) put forward that interest and autonomy in using ICT were positively related to achievements. According to the findings related to the third sub-problem, Turkish students' success in science based on PISA 2018 data due to differences between students is $44 \%$ of the total variance while it is 
$56 \%$ due to differences between schools. The rate of explanation of Turkish students' science achievement by school variables considered at the second level is only $6 \%(10 \% * 56 \%)$. The review between the years 2000-2012 which was conducted by Zhang and Liu (2016) also showed that the relationship between ICT and math and science achievement in participating countries' school-level ICT-related variables had a positive impact on achievement.

In this study, it was also found that in Turkey when computer availability per student at school increases, science success decreases significantly. In PISA 2015 depending on the number of computers per student there was an increase in the achievements only for the low-intensity users with disadvantaged backgrounds and also, 'ICTSCH' was found to be positively related to achievement at schools with fewer computers per student with lowintensity users (Rodrigues \& Biagi, 2017). In our study, the number of digital devices for instruction was found to be positively related to science achievement. School resources seem to be important to close the gap of accessing technology between advantaged and disadvantaged students. However, this occurs only when the devices are used for instruction.

With this study as in the other studies, it can be said that the ICT skills should be evaluated frequently to get a picture of related time as the technologies are fast-growing and it is a still-developing area. The relationship of the ICT and achievement or integration of ICT in education has been discussed in several studies and will be discussed in the future. Due to COVID-19 the swift shift to the digitalization of education has shown us that we need to rethink all the relationships between ICT and education.

\section{Conclusion}

In this study, the relationship between ICT and science academic achievement was put forward. It can be concluded that our understanding will be shaped by looking into details of how this generation uses and engages in ICT and what the relationship between ICT and the educational objectives will be. Nowadays, it is not possible to shape the future of ICT in education with the policymakers' decisions but the generation itself will shape it. This study provides data about how new generations have a different understanding of engagement with ICT from the policymakers and educators. There are some expected results but also surprising ones. As expected, ICT resources and ICT classes have a positive effect on 
students' learning. This result may mean that we need to use ICT more often in our classes and the resources in the classes are important. In addition, when students feel competent, their success also increases. On the other hand, a surprising result is that ICT availability at school has no relation to achievement. It can be explained with the usage purpose of the ICT at school. ICT may not be in use of the students or students may use their own devices at school. Moreover, different from the expected, when they use ICT at home for school work, it has a negative effect on their success. Also, when they use ICT for social interaction it has a negative effect on their learning. Normally, it is expected that competence and autonomy can be improved by using ICT for social interaction so it may facilitate the transfer of the knowledge of strategies for learning outside the class. These results may be related to the fact that the duration they are engaged with their digital devices is not for school-related activities. The amount of time they spend on social interaction outside the school may affect their time allocated for studying school subjects.

Furthermore, the rate of explanation of student and school differences is not high. The variables of school level like the number of digital devices for instruction significantly increases science success in PISA 2015 (Rodrigues \& Biagi, 2017) but in our study, it was found that there was a negative correlation between the computer availability at school and science success. Another surprising finding is that the teachers' pedagogical skills to integrate digital devices in instruction have no relation to the success of the students. It can be said that the autonomy of the students may be more important than the skills of the teachers or they may not use their skills effectively. As seen in the rapid digital transition due to COVID-19, teachers have struggled with online learning. It is an obvious fact that teachers need training in digital education (UN news, 2020) because they will use digital devices more than ever. Before COVID-19 online learning support platforms were not in use at every school so it is not surprising that it had no significant impact on achievement but this determinant should be evaluated after COVID-19 to get a better understanding of the future situation.

In conclusion, while having ICT at home and using ICT for school work at home and the school have negative effects on science achievement in line with students' opinions, having ICT resources and using ICT in the classroom for instruction have positive effects. According to the views of school administrators, while having a computer for every student at school has a negative effect on science achievement; adequate digital tools for teaching 
have a positive effect. As a result, increasing the diversity of digital tools in a systematic, purposeful, and determined way to attract students' attention will contribute to student success. Therefore, while increasing the quality of education, it becomes more important to focus on how to use ICT and integrate them into the lessons. Besides, parents should be a part of this issue and need to get training on students' usage of ICT outside the school. This may help students to use ICT purposefully outside the school. Moreover, to increase teachers' knowledge and skills, teachers should be given support with both pre-service and professional development programs on how to effectively integrate ICT into lessons because of the increase in the usage of learning support platforms. As teachers, curriculum and resources have significant roles to shape the students' success, teachers need to be supported with "the right environment, infrastructure, devices, and leadership support" and "digitallysupported teaching approach" should be adapted for teacher training, curricula, and educational materials (EU, 2018, p. 5).

Nowadays, analyzing the ICT skills of the students and the ICT variables at the school level is more important than ever. Therefore, for future studies, the revised version of the PISA 2021 assessment will give a better and clearer picture of the relationship between the achievements of the students in all domains and ICT. During the pandemic, educational disparities concerning ICT become clearer so ICT and SES relationship can be analyzed. Also, future studies can be conducted by comparing the countries and the years which will be beneficial to see the improvements, impact on achievements, and disparities in education related to ICT, especially after the pandemic.

Acknowledgement

The data used in this study does not require the approval of Institutional Ethical Review Board.

Author Contribution Statement

Volkan Hasan KAYA: Conceptualization, methodology, data analysis and control preliminary draft writing and editing.

Sibel INCI: Conceptualization, methodology, preliminary draft writing and editing, reviewwriting and editing. 


\section{References}

Anıl, D. \& Özer, Y. (2012). The effect of the aim and frequency of computer usage on student achievement according to PISA 2006. Procedia-Social and Behavioral Sciences, 46, 54845488.

Cheema, J. R. \& Zhang, B. (2013). Quantity and quality of computer use and academic achievement: Evidence from a large-scale international test program. International Journal of Education and Development using Information and Communication Technology (IJEDICT), 9(2), 95-106.

Delen, E., \& Bulut, O. (2011). The relationship between students' exposure to technology and their achievement in science and math. The Turkish Online Journal of Educational Technology, 10, 311-317.

Elçiçek, M.. \& Erdemci, H. (2021). Investigation of 21st-century competencies and e-learning readiness of higher education students on the verge of digital transformation. Journal of Computer and Education Research, 9 (17), 80-101. DOI: 10.18009/jcer.835877

Erdoğdu, F., \& Erdoğdu, E. (2015). The impact of access to ICT, student background and school/home environment on academic success of students in Turkey: An international comparative analysis. Computers \& Education, 82, 26-49.

EU (2018). Communication from the commission to the european parliament, the council, the European economic and social committee and the committee of the regions: On the digital education action plan. Retrieved from https://eur-lex.europa.eu/legalcontent/EN/TXT/PDF/?uri=CELEX:52018DC0022\&from=EN

EU (2020). Digital education action plan. https://ec.europa.eu/education/education-in-theeu/digital-education-action-plan_en

Hu, X., Gong, Y., Lai, C., \& Leung, F. K. (2018). The relationship between ICT and student literacy in mathematics, reading, and science across 44 countries: A multilevel analysis. Computers \& Education, 125, 1-13.

Hughes, C. (2020). Some implications of COVID-19 for remote learning and the future of schooling. In progress reflection No. 36. On current and critical issues in curriculum, learning and assessment, UNESCO International Bureau of Education. Retrieved from https://unesdoc.unesco.org/ark:/48223/pf0000373229

Jerrim, J., Lopez-Agudob, L. A., Marcenaro-Gutierrezb, O. D. \& Shure, N. (2017). What happens when econometrics and psychometrics collide? An example using the PISA data. Economics of Education Review, 61, 51-58.

Kubiatko, M. \& Vlčková, K. (2010). The relationship between ICT use and science knowledge for Czech students: A secondary analysis of PISA 2006. International Journal of Science and Mathematics Education, 8(3), 523-543. https://doi.org/10.1007/s10763-010-9195-6

Kunina-Habenicht, O. \& Goldhammer, F. (2020). ICT engagement: A new construct and its assessment in PISA 2015. Large-scale Assessments in Education, 8(6), 1-21.

Lorenceau, A., Marec C. \& Mostafa, T. (2019). Upgrading the ICT questionnaire items in PISA 2021. OECD Education Working Paper No. 202. 
Luu, K. (2009). An analysis of the relationship between information and communication technology (ICT) and scientific literacy in Canada and Australia. [Unpublished master's thesis]. Queen's University Kingston.

Meng, L., Qiu, C. \& Boyd-Wilson, B. (2019). Measurement invariance of the ICT engagement construct and its association with students' performance in China and Germany: evidence from PISA 2015 data. British Journal of Educational Technology, 50(6), 32333251. https://doi.org/10.1111/bjet.12729

Odell, B., Galovan, A. M. \& Cutumisu, M. (2020). The relation between ICT and science in PISA 2015 for Bulgarian and Finnish students. Eurasia Journal of Mathematics, Science and Technology Education, 16(6), 1-15. https://doi.org/10.29333/ejmste/7805

OECD (2019). PISA 2018 assessment and analytical framework, OECD Publishing, Retrieved from https://doi.org/10.1787/b25efab8-en.

Papanastasiou, E. C., Zembylas, M., \& Vrasidas, C. (2003). Can computer use hurt science achievement? The USA results from PISA. Journal of Science Education and Technology, 12(3), 325-332. https://doi.org/10.1023/A:1025093225753

Park, Y. (2017). How can we help kids protect themselves online? Retrieved from https://www.weforum.org/agenda/2017/01/digital-danger-kids-protect-themselves-online/

Raudenbush, S. W., \& Bryk, A. S. (2002). Hierarchical Linear Models: Applications and data analysis methods (2nd ed.). Sage Publications, Inc.

Rodrigues, M. \& Biagi, F. (2017). Digital technologies and learning outcomes of students from low socio-economic background: An Analysis of PISA 2015. Publications Office of the European Union. Retrieved from https://doi.org/10.2760/415251

Spiezia, V., (2010). Does computer use increase educational achievements? Student-level evidence from PISA. OECD Journal: Economic Studies, 1, 1-22.

UN News (2020). Startling disparities in digital learning emerge as COVID-19 spreads: UN education agency. Retrieved from https://news.un.org/en/story/2020/04/1062232.

Zhang, D. \& Liu L. (2016). How does ICT use influence students' achievements in math and science over time? Evidence from PISA 2000 to 2012. Eurasia Journal of Mathematics, Science \& Technology Education, 12(9),2431-2449.

\section{Appendix}

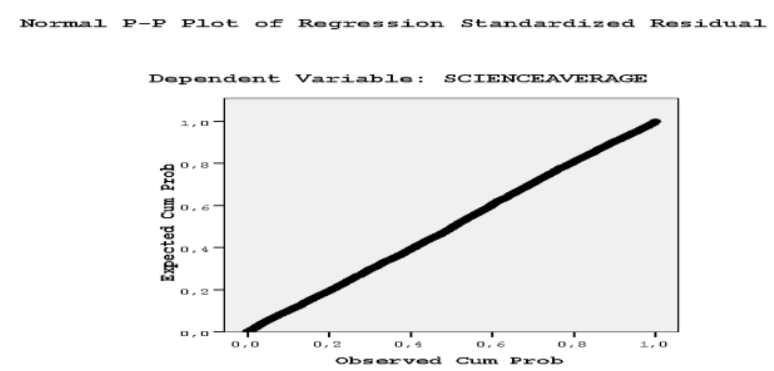

Figure 1. P-P Plot Regression

Copyright $($ JCER

JCER's Publication Ethics and Publication Malpractice Statement are based, in large part, on the guidelines and standards developed by the Committee on Publication Ethics (COPE). This article is available under Creative Commons CC-BY 4.0 license (https://creativecommons.org/licenses/by/4.0/) 